\title{
Awards and Honors
}

\section{Dana Knox Receives the Franzosini Award}

Paolo Franzosini, professor of Physical Chemistry at the University of Pavia, Italy was an enthusiastic supporter of the Solubility Data Project. He had almost completed Volume 33 of the Solubility Data Series when he died suddenly on 24 January 1985. His colleagues Paolo Ferloni, Alberto Schiraldi, and Giorgio Spinolo efficiently completed the volume. In 1988, Franzosini's wife, with the encouragement of his colleagues, very generously donated the payments for Volume 33 to the Solubility Data Commission (V.8) to establish the Franzosini Award. The award is given to a promising young contributor to the Solubility Data Project (SDP) to help them attend, in even years, the International Symposium on Solubility Phenomena (ISSP) and, in odd years, the annual meetings of the commission. As of

\section{Franzosini Award Winners*}

\begin{tabular}{|c|c|c|c|}
\hline Year & Venue & Recipient & Promoter \\
\hline 1989 & 15th meeting, Lund, Sweden & $\begin{array}{l}\text { Rumen Duhlev } \\
\text { (Bulgaria) }\end{array}$ & Chr. Balarew \\
\hline 1990 & $\begin{array}{l}\text { 16th meeting, Troy, NY, USA } \\
\text { 4th ISSP }\end{array}$ & $\begin{array}{l}\text { Pirketta Scharlin } \\
\text { (Finland) }\end{array}$ & R. Battino \\
\hline 1991 & $\begin{array}{l}\text { 17th meeting, Hamburg, } \\
\text { Germany }\end{array}$ & $\begin{array}{l}\text { A. Pacheco Tanaka } \\
\text { (Peru) }\end{array}$ & A. Namor \\
\hline 1992 & $\begin{array}{l}\text { 18th meeting, Moscow, Russia } \\
5 \text { th ISSP }\end{array}$ & $\begin{array}{c}\text { Stefan Gradinarov } \\
\text { (Bulgaria) }\end{array}$ & Chr. Balarew \\
\hline 1993 & 19th meeting, Lisbon, Portugal & $\begin{array}{c}\text { Michel Ferriol (France) and } \\
\text { Teresa Calvet (Spain) }\end{array}$ & M.-Th. Cohen-Adad \\
\hline 1994 & $\begin{array}{l}\text { 20th meeting, Buenos Aires, } \\
\text { Argentina } \\
6 \text { th ISSP }\end{array}$ & $\begin{array}{l}\text { Erich Königsberger } \\
\text { (Austria) }\end{array}$ & H. Gamsjäger \\
\hline 1995 & 21st meeting, Guildford, UK & $\begin{array}{l}\text { Felix José Sueros } \\
\text { (Peru) }\end{array}$ & A. Namor \\
\hline 1996 & 22nd meeting, Leoben, Austria & - & \\
\hline 1997 & $\begin{array}{l}\text { 23rd meeting, Geneva, } \\
\text { Switzerland }\end{array}$ & & \\
\hline 1998 & $\begin{array}{l}\text { 24th meeting, Niigata, Japan } \\
\text { 8th ISSP }\end{array}$ & $\begin{array}{l}\text { Lan-Chi Tran-Ho } \\
\text { (Austria) }\end{array}$ & H. Gamsjäger \\
\hline 1999 & 25th meeting, Berlin, Germany & $\begin{array}{l}\text { Chiara Milanese } \\
\text { (Italy) }\end{array}$ & A. D'Aprano \\
\hline 2000 & $\begin{array}{l}\text { 26th meeting, Hammamet, } \\
\text { Tunesia } \\
\text { 9th ISSP }\end{array}$ & $\begin{array}{l}\text { Vladimir Zbranek } \\
\text { (Czech Republic) }\end{array}$ & J. Eysseltová \\
\hline 2001 & 27th meeting, Brisbane, Australia & $\begin{array}{l}\text { Justin Salminen } \\
\text { (Finland) }\end{array}$ & P. Scharlin \\
\hline 2002 & $\begin{array}{l}\text { 1st meeting SSED, Varna, } \\
\text { Bulgaria } \\
\text { 10th ISSP }\end{array}$ & $\begin{array}{l}\text { Dana E. Knox } \\
\text { (USA) }\end{array}$ & R. P.T. Tomkins \\
\hline
\end{tabular}

2002, the chair of the new Subcommittee on Solubility and Equilibrium Data (SSED) receives nominations for the award (The capital is held by IUPAC and the IUPAC Secretariat does the accounting.). The recipients of the
Franzosini Award are listed in the table below.

The Franzosini Award of 2002 was given to Dr. Dana Knox in appreciation of his continuous contributions to the Solubility Data Project. His expertise in solution thermodynamics, including better representation of high-pressure phase equilibria, such as supercritical

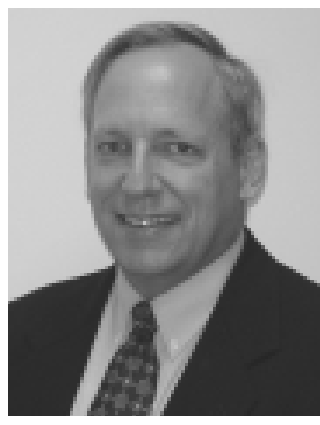
solubilities has led to the following project on Solids and Liquids in Supercritical Carbon Dioxide, which belongs to the section on Solubility Data Related to Industrial Processes. See the Web site for the project description <www.iupac.org/projects/2002/2002-045$1-500 . \mathrm{html}>$ or page 20, under "New Solubility Data Projects."

Carbon dioxide itself is an important industrial solvent. The corresponding volume will contain comprehensive compilations and evaluations of the existing data on the solubility of solids and liquids in supercritical $\mathrm{CO}_{2}$. Processing using supercritical fluids is an increasingly important area worldwide. Such processes, with their significant variation in solubility with pressure, permit the accomplishment of many processes that would be otherwise very difficult to achieve. Further, systems that employ carbon dioxide as the solvent are particularly attractive as $\mathrm{CO}_{2}$ is environmentally friendly.

Dr. Knox is associate professor of Chemical Engineering and Environmental Science within the Department of Chemical Engineering at the $\mathrm{New}$ Jersey Institute of Technology (USA). 